\title{
BLOOD GLUCOSE LEVELS DON'T RISE AFTER CORTISOL ADMINISTRATION IN ALZHEIMER'S DISEASE PATIENTS
}

\section{AMOS GELBARD*}

Zefat Academic College, College in Safed, Israel. Email: amosgelbard@gmail.com

Received: 16 February 2021, Revised and Accepted: 27 March 2021

(C) 2021 The Authors. Published by Innovare Academic Sciences Pvt Ltd. This is an open access article under the CC BY license (http://creativecommons. org/licenses/by/4.0/) DOI: http://dx.doi.org/10.22159/ijms.2021v9i3.41145. Journal homepage: https://innovareacademics.in/journals/index.php/ijms

Cortisol is secreted by the adrenal glands when a person is facing a stressful situation. It stimulates a rise in blood glucose levels, to run faster when facing a lion, for example.

HyperCortisolemia in Alzheimer's Disease (AD) [1] is thought to be not just a consequence but to have a role in the manifestation of the disease [2].

It is been reported that glucocorticoid administration increases Amyloid Beta formation and augments tau accumulation inside the brain [2], explaining how cortisol overflow could be the cause for the main hallmarks of the disease.

Another study researched cortisol and its impact on hippocampal glucose metabolism [3], but also found something else, something the research team barely mentioned.

They have found that cortisol administration led to a rise in blood glucose levels, but only in the control group and not among Alzheimer's patients.

"Blood collected during the positron emission tomography scans showed, for the normal group, a rise in plasma glucose levels, starting approximately $25 \mathrm{~min}$ after hydrocortisone administration. The AD group did not show this effect..." [3].
This abnormality lies in the most basic process of cortisol secretion leading to a rise in blood glucose levels. Plenty of research centers around Cortisol in AD but I couldn't find anywhere else any mention of this so basic malfunction.

I urge further research, to examine if blood glucose levels in $\mathrm{AD}$ patients are in fact not responding to cortisol secretion (or administration). This could bring new ideas on how to solve this impairment and solving it could perhaps prove beneficial for $\mathrm{AD}$ treatment as a whole.

\section{REFERENCES}

1. Lei JK. Change of serum ACTH and cortisol levels in Alzheimer disease and mild cognition impairment. Zhonghua Yi Xue Za Zhi 2010;90:2894-6.

2. Green KN, Billings LM, Roozendaal B, McGaugh JL, LaFerla FM. Glucocorticoids increase amyloid- $\beta$ and tau pathology in a mouse model of Alzheimer's disease. J Neurosci 2006;26:9047-56.

3. de Leon MJ, McRae T, Rusinek H, Convit A, De Santi S, Tarshish C, et al. Cortisol reduces hippocampal glucose metabolism in normal elderly, but not in Alzheimer's disease. J Clin Endocrinol Metabol 1997;82:3251-9. 